University of Nebraska - Lincoln

DigitalCommons@University of Nebraska - Lincoln

Publications from USDA-ARS / UNL Faculty

U.S. Department of Agriculture: Agricultural

Research Service, Lincoln, Nebraska

1993

\title{
Registration of 'Manska' Pubescent Intermediate Wheatgrass
}

\author{
J. D. Berdahl \\ USDA-ARS \\ R. E. Barker \\ USDA-ARS \\ J. F. Karn \\ USDA-ARS \\ J. M. Krupinsky \\ USDA-ARS \\ I. M. Ray \\ USDA-ARS
}

See next page for additional authors

Follow this and additional works at: https://digitalcommons.unl.edu/usdaarsfacpub

Berdahl, J. D.; Barker, R. E.; Karn, J. F.; Krupinsky, J. M.; Ray, I. M.; Vogel, Kenneth P.; Moore, K. J.;

Klopfenstein, Terry J.; Anderson, B. E.; Haas, R. J.; and Tober, D. A., "Registration of 'Manska' Pubescent Intermediate Wheatgrass" (1993). Publications from USDA-ARS / UNL Faculty. 1901.

https://digitalcommons.unl.edu/usdaarsfacpub/1901

This Article is brought to you for free and open access by the U.S. Department of Agriculture: Agricultural Research Service, Lincoln, Nebraska at DigitalCommons@University of Nebraska - Lincoln. It has been accepted for inclusion in Publications from USDA-ARS / UNL Faculty by an authorized administrator of DigitalCommons@University of Nebraska - Lincoln. 


\section{Authors}

J. D. Berdahl, R. E. Barker, J. F. Karn, J. M. Krupinsky, I. M. Ray, Kenneth P. Vogel, K. J. Moore, Terry J. Klopfenstein, B. E. Anderson, R. J. Haas, and D. A. Tober 


\section{References and Notes}

1. Busch, R., D. McVey, T. Rauch, J. Baumer, and F. Elsayed. 1984. Registration of Wheaton wheat. Crop Sci. 24:622.

2. R. Busch and D. McVey, USDA-ARS, Univ. of Minnesota, St. St. Paul, MN 55108; J. Wiersma, Univ. of Minnesota, Crookston, MN 56716; D. Warnes, Univ. of Minnesota, Morris MN 56267; R. Wilcoxson, Univ. of Minnesota, St. Paul, MN 55108; and G. Hareland,
USDA-ARS, Fargo, ND 58105. Cooperative investigations of the Minnesota Agric. Exp. Stn. and USDA-ARS, and research was supported in part by a grant from the Minnesota Wheat Res. and Promotion Council. Published as Journal Series no. 19,929. Registration by CSSA. Accepted 30 Nov 1992. "Corresponding author.

Published in Crop Sci. 33:880-881 (1993).

\section{Registration of 'Manska' Pubescent Intermediate Wheatgrass}

'MANSKA' pubescent intermediate wheatgrass [Thinopyrum intermedium subsp. barbulatum (Schur) Barkw. \& Dewey] (Reg. no. CV-21, PI 562527) was tested as Mandan I2781 and released 16 April 1992 by the USDA-ARS in cooperation with the USDA-SCS; the Agricultural Research Division, Institute of Agriculture and Natural Resources, University of Nebraska; and the North Agricultural Experiment Station.

Manska, a population derived from 116 parent clones, traces to PI 116252, a pubescent intermediate wheatgrass accession presented to the USDA in 1936 by the renowned Russian botanist, N. I. Vavilov (1). Testing of PI 116252 and other intermediate wheatgrass introductions was initiated at the USDAARS Northern Great Plains Research Laboratory, Mandan, ND in 1938 (G. A. Rogler, 1991, personal communication). A population selected from PI 116252 was designated Mandan 759 pubescent intermediate wheatgrass, an experimental strain that has had wide commercial use but has never been formally released as a cultivar (2). The source population for Manska consisted of 5160 individually spaced plants from 11 different seed lots of Mandan 759. Plants with pubescent seed heads varied from 20 to $75 \%$ among the 11 seed lots, indicating that most of the seed lots had been subjected to outcrossing or seed admixture with glabrous plants in the intermediate wheatgrass complex. A six-replicate, 120 -entry polycross nursery was established with plants that were selected from the source population based on their vigor, pubescence, and resistance to leafspot disease caused primarily by Cochliobolus sativus (Ito \& Kuribayoshi) Drechs. ex Dastur. Polycross progenies were evaluated for resistance to leaf-spot disease, spring recovery, nutritional quality, and forage and seed yields. Equal quantities of seed from 116 parent entries in the polycross nursery were composited to produce the experimental strain Mandan I2781 (Manska) and to establish a breeder seed field. Breeder seed fields can be reestablished from Syn-1 seed maintained in cold storage at Mandan.

High nutritive value is the primary advantage of Manska over current intermediate wheatgrass cultivars. In tests at Mandan, Manska averaged significantly higher $(P \leq 0.05)$ in vitro digestible organic matter at anthesis than the commonly grown check cultivar Oahe ( $\left.620 \mathrm{vs.} 563 \mathrm{~g} \mathrm{~kg}^{-1}\right)$. In vitro dry matter digestibility at anthesis was significantly $(P \leq 0.05)$ higher for Manska than Oahe (590 vs. $573 \mathrm{~g} \mathrm{~kg}^{-1}$ ) when averaged over $2 \mathrm{yr}$ and three test sites in Nebraska. At Mead, Nebraska, daily gains of yearling steers averaged 1.22 and $1.06 \mathrm{~kg}$, respectively, for Manska and Oahe $(P \leq 0.05)$ over two grazing periods at a stocking rate of 7.4 steers ha-1 ${ }^{-1}$ Weight gains averaged over the two grazing periods were 298 and $257 \mathrm{~kg}$ ha $^{-1}$, respectively, for Manska and Oahe $(P \leq 0.05)$. Dry matter yields averaged over 15 station-years at four test sites in North Dakota were 4226,4228 , and $4509 \mathrm{~kg} \mathrm{ha}^{-1}$, respec- tively, for Manska, Oahe, and 'Reliant', a 6\% advantage (nonsignificant) for the recently released cultivar, Reliant (formerly Mandan I1813). In Nebraska, dry matter yields from eight station-years at three test sites averaged 5750 and $6050 \mathrm{~kg} \mathrm{ha}^{-1}$ for Manska and Oahe, respectively, a 5\% yield advantage (nonsignificant) for Oahe. Seed yields averaged over 12 stationyears at four test sites in North Dakota and Saskatchewan were 427 and $489 \mathrm{~kg} \mathrm{ha}^{-1}$, respectively, for Manska and Reliant, a $13 \%$ advantage $(P \leq 0.05)$ for Reliant. Twenty-seven percent of the plants from the breeder seed population of Manska had no pubescence on the seed heads, while the remainder of the population was rated as $8 \%$ heavily, $19 \%$ moderately, and $46 \%$ lightly pubescent.

Manska is recommended for pasture and hay in regions of the northern and central Great Plains where annual precipitation averages more than $350 \mathrm{~mm}$. No data exist on long-term persistence of Manska under grazing. Based on performance of other intermediate wheatgrass cultivars, maintenance of Manska at a high stand density under grazing would likely require prudent management to assure adequate fall-season recovery, especially when stressed from drought or exposed to high levels of winter stress in the northern Great Plains.

Breeder seed of Manska pubescent intermediate wheatgrass will be maintained by USDA-ARS, Northern Great Plains Research Laboratory, P.O. Box 459, Mandan, ND 58554. One generation each of foundation and certified seed beyond breeder seed is authorized. Foundation seed will be available from the USDA-SCS Plant Materials Center, P.O. Box 1458, Bismarck, ND 58502 and the Foundation Seed Division, Department of Agronomy, University of Nebraska, Lincoln, NE 68583.

J. D. Berdahl, * R. E. Barker, J. F. Karn, J. M. KRUPINSKY, I. M. RAY, K. P. Vogel, K. J. MOORE, T. J. Klopfenstein, B. E. Anderson, R. J. HaAs, AND D. A. TOBER (3)

\section{References and Notes}

1. Anon. 1941. Plant material introduced by the Division of Plant Exploration and Introduction, U.S. Bur. Plant Industry, 1 April-30 June 1936 (no. 114314-116965). Inventory no. 127. Beltsville Agric. Research Center, Beltsville, MD.

2. Hanson, A. A. 1972. Grass varieties in the United States. USDA Agric. Handb. 170. U.S. Gov. Print. Office, Washington, DC.

3. J. D. Berdahl, J. F. Karn, J. M. Krupinsky, and I. M. Ray, USDAARS, Northern Great Plains Research Lab., P.O. Box 459, Mandan, ND 58554; R. E. Barker, USDA-ARS, National Forage Seed Prod. Res. Ctr., 3450 S. W. Campus Way, Corvallis, OR 97331-7102; K. P. Vogel and K. J. Moore, USDA-ARS, Wheat, Sorghum, and Forage Research, Dept. Agron., Univ. Nebraska, Lincoln, NE 68583; R. J. Haas and D. A. Tober, USDA-SCS, P.O. Box 1458, Bismarck, ND 58502; B. E. Anderson, Dept. Agron., Univ. Nebraska, Lincoln, NE 68583; and T. J. Klopfenstein, Dep. An. Sci., Univ. Nehbraska, Lincoln, NE 68583. Registration by CSSA. Accepted 30 Nov. 1992. *Corresponding author.

Published in Crop Sci. 33:881 (1993). 